\section{Research Article}

(c) 2021 Corry Yohana.

This is an open access article licensed under the Creative Commons Attribution-NonCommercial 4.o International License (https://creativecommons.org/licenses/by-nc/4.o/)

\title{
Recognition of Entrepreneurship Program in Independent Campus Policies: Indonesian Case
}

\author{
Corry Yohana \\ Faculty of Economic, State University of Jakarta, \\ Jalan Rawamanun Muka (Rawamangun Jakarta Timur), \\ Jakarta, DKI Jakarta, Indonesia
}

DOI: https://doi.org/10.36941/jesr-2021-0075

\begin{abstract}
This paper aims to explain the factors that influence entrepreneurship programs in the Independent Campus policy. This paper is part of an Independent Campus policy study initiated by the Ministry of Education and Culture of the Republic of Indonesia in 2020 with objects in 5 (five) universities: 2 (two) accredited A, 2 (two) accredited B, and 1 (one) accredited C The data was collected through on-line discussions, particularly regarding entrepreneurship programs. This study also distributed questionnaires related to questions about entrepreneurship programs to respondents from representatives of rectorate leaders, faculties, study programs, lecturers, and others. The analysis was carried out through quantitative techniques with the help of the Lisrel 87.o program technique, enriched with qualitative techniques based on information obtained from on-line discussions. The results of the study found that campus policy factors, apprenticeship programs, and exploration of local potential had a positive effect on competency development, application, and entrepreneurship learning. In addition, learning that takes into account these factors also affect students' commitment to become entrepreneurs after completing their studies. The implementation of entrepreneurship programs must pay attention to these influencing factors, the contribution of indicators for each factor, and apply recognition related to standard processes and achievement of competency program results.
\end{abstract}

Keywords: independent campus, program, entrepreneurship, competence, recognition

\section{Introduction}

One of the student learning activities in the Independent Campus (Indonesia: Kampus Merdeka) policy to fulfill students' right to study for 2 (two) semesters is the entrepreneurship program. This program can be selected by students by obtaining 20 credits per semester / 40 credits per year to develop competency and work readiness of higher education graduates, so as to avoid unemployment. The other seven programs that can be chosen are: student exchange, work apprenticeship, teaching assistance in schools, research, humanitarian projects, independent projects, and real thematic village / lecture development (Directorate General of Higher Education, 2020).

The issuance of the Independent Campus policy by the Minister of Education and Culture of the Republic of Indonesia has two objectives: on the one hand it seeks to develop the competence of college graduates to be ready to work after graduating, on the other hand to anticipate and respond to the development of the industrial revolution 4.o. The latter not only resulted in a change in the 
employment situation in the form of a large number of job losses in various sectors but also created new jobs that relied on digital technology. If it is not anticipated and responded to early, universities will only produce graduates who are less competent, competitive, and ready to work, and tend to increase the number of unemployed that have previously existed (table 1).

Table 1. Unemployment According to Education Attended 2014- 2018

\begin{tabular}{|c|l|c|c|c|c|c|}
\hline No. & Education & 2014 & 2015 & 2016 & 2017 & \multicolumn{2}{c|}{2018} \\
\hline 1 & Never to school & 74.898 & 55.554 & 59.346 & 62.984 & 31.774 \\
\hline 2 & Not completed in primary school & 389.550 & 371.542 & 384.069 & 404.435 & 326.962 \\
\hline 3 & Primary school & 1.229 .652 & 1.004 .961 & 1.035 .731 & 904.561 & 898.145 \\
\hline 4 & Junior High School & 1.566 .838 & 1.373 .919 & 1.294 .483 & 1.274 .417 & 1.131 .214 \\
\hline 5 & High school & 1.962 .786 & 2.280 .029 & 1.950 .626 & 1.910 .829 & 1.930 .320 \\
\hline 6 & Vocational high school & 1.332 .521 & 1.569 .690 & 1.520 .549 & 1.621 .402 & 1.731 .743 \\
\hline 7 & Academy / Diploma & 193.517 & 251.541 & 219.736 & 242.937 & 220.932 \\
\hline 8 & University & 495.143 & 653.586 & 567.235 & 618.758 & 729.601 \\
\hline & Total & 7.244 .905 & 7.560 .822 & 7.031 .775 & 7.005 .262 & 7.000 .761 \\
\hline
\end{tabular}

Source: Central Statistics Agency, Jakarta, 2019.

The Independent Campus Policy is an anticipatory, responsive, and futuristic action towards developments and changes in labor conditions in the era of the industrial revolution 4.o. The entrepreneurship option program not only develops the competence of higher education graduates to be independent and create jobs, but also increases the number of entrepreneurs in Indonesia. Especially the latter, economists argue that the economic resilience of a country can be seen from the indicator of the ratio of the number of entrepreneurs to the total population. On average, developed countries with stable economies have an entrepreneurial ratio of 14 percent compared to their total population. In Indonesia, the ratio of the number of entrepreneurs is still low, although from year to year the number shows an increasing trend (Yohana, Dania, \& Prihandono, 2021). Data from the Central Statistics Agency (2019) notes that the number of entrepreneurs in Indonesia has increased from 1.56 percent in 2014 to 3.1 percent in 2016, but is still relatively small compared to the population of 267 million. The effort that needs to be done is how to increase it to 14 percent. Even in 2020 the number of entrepreneurs tends not to increase, even decreases for various reasons (Bisnis, 2019; Yohana, Dania, \& Prihandono, 2021).

It is hoped that the Independent Campus policy will encourage the growth of student interest in choosing and fostering entrepreneurship after graduating. The selection of entrepreneurship programs during college is expected to be able to guide students, develop their competencies and expertise, and be involved in the world of entrepreneurship. However, entrepreneurship education in higher education is not new, it has even been taught for a long time. The result is still not able to involve the participation of college graduates to work in this field. What are the factors that cause entrepreneurship education has not been able to attract college graduates, even though many of them fall into unemployment?

On the other hand, the implementation of this entrepreneurship program still raises questions, how do students recognize the achievement of learning competencies for this program? What criteria are used to measure success? How can this entrepreneurship program be realized and become a work orientation for college graduates later? On that basis, this paper wants to analyze the factors that influence the application of entrepreneurship education, the introduction of student entrepreneurial competencies, and alternatives that need to be implemented by the government. 


\section{Literature Review}

\subsection{Entrepreneurship Program}

One of the programs in the Independent Campus policy is entrepreneurship. In simple terms, entrepreneurship can be defined as someone who has the ability to create and implement new technology and products by increasing efficiency and obtaining maximum profits. Entrepreneurship can be said as a process to get business opportunities (https://saintif.com/ Understandentrepreneurship /). Entrepreneurship is a process of becoming an entrepreneur who has the characteristics of high self-confidence, risk-taking, leadership, persistence, independence, always looking for opportunities, etc. (Kao, 1995, 2006; DuBrin, 2004; Zimmemer 2005; Tan, 2007; Robbin \& Coulter, 2018).

An entrepreneur does not depend on other people's work, but independently creates and develops his business. On that basis, the government in its policy implements entrepreneurship programs as an option that students can take in their studies. The entrepreneurship program aims to equip students who have entrepreneurial interests to develop their businesses earlier and with more direction, in dealing with the problem of college graduate unemployment. Learning activities by students are regulated in the study program curriculum which is guided by a lecturer (Directorate General of Higher Education, 2019).

\subsection{Entrepreneurship Learning}

Entrepreneurship education in universities in Indonesia has been implemented for a long time. There are two goals, on the one hand to provide knowledge and provisions for graduates to grow entrepreneurship after graduation, on the other hand to increase the number of entrepreneurs. Entrepreneurship is a form of breakthrough so that college graduates do not always depend on jobs that come from the government or the private sector, but are creative and innovative in creating and developing their own jobs. Entrepreneurship education, which has been facilitated by the Directorate General of Higher Education since 1997, offers various activities, including: entrepreneurship courses, entrepreneurship internships for business work, business consultations and job placements, as well as new entrepreneur incubators. In its journey, many universities reject entrepreneurship education because it is considered business education, even though many study programs consider it not educating students or graduates to become entrepreneurs (Susilaningsih, 2015).

However, in the Independent Campus policy, entrepreneurship programs are still open and can be chosen by students. Entrepreneurship program policies can be studied by all students from various fields of science as education and training that allows students to develop their creativity, take initiative, be responsible and risky. Thus, entrepreneurship education is not only focused on business, but must be interpreted as the spirit, behavior, and ability to take initiatives, organize and rearrange social and economic mechanisms to change resources and situations to be more beneficial and profitable; and take risks and fail. Entrepreneurship education is a dynamic process to create something new of value by devoting the necessary time and energy, taking financial, psychological and social risks, and obtaining results in the form of financial, personal satisfaction and freedom (de Clerk \& Krueger, 2002; Hisrich, Peters, \& Shepherd, 2009; Drucker, 2007; Directorate General of Higher Education, 2020).

\subsection{Competency Development}

Entrepreneurship education is expected to be literacy in developing graduate competencies to identify, understand, interpret, create, and realize business forms after completing studies (Montoya, 2018). With entrepreneurial competence, college graduates have the ability to integrate entrepreneurial knowledge, skills, attitudes and behaviors based on the potential around them. The theory and practice 
of entrepreneurship learning fosters creativity and innovation, independence, and entrepreneurship after completing education through the utilization of local potential, cooperation with business actors, suppliers of goods, service providers, and others (Yohana, Dania, \& Prihandono, 2021).

At the same time, experts believe that entrepreneurial competence needs to underpin a number of traits of business behavior to achieve success. These characteristics include: self-confidence, initiative, task and result oriented, risk taking, leadership behavior, forward-looking, disciplined, working together, building good relationships, learning new things, utilizing science and technology, thinking positively, improving added value, being creative and innovative to make changes, sensitive to the environment, seeking information continuously, etc. (Meredith et al, 1982; Meredith, 1992; Hisrich, Peters, and Shepherd, 2009; Yohana, Dania, \& Prihandono, 2021). With entrepreneurship education, one of which is expected to prevent college education graduates from becoming unemployed.

\subsection{Environmental Potential}

The environment often contains the potential to encourage creativity and innovation in the field of entrepreneurship. The natural and social physical environment often contains potential that can be utilized as a source of business, for example: entrepreneurship in the development of aspects of tourism, handicrafts, trade services, transportation services. courses / training, culinary, mechanical services, and others (Haryani, 2012; Supardi \& Mulyati, 2013; Kardiyono, 2014; Ratumbuysang \& Rasyid, 2015).

That is, the emergence of creative and innovative attitudes of business can be come from outside (already in other places but not yet known in one area (for example: computer and internet rental services), but it can also take advantage of environmental potentials that can actually become business prospects. Currently, people are competing to come up with creative and innovative ideas and behavior by exploring, designing, developing, and exploiting the potential of the natural environment to become a tourist attraction. Development has often succeeded in attracting tourists, which has led to other types of business, such as transportation services, culinary, photographers, hospitality, lodging, resident rooms, and so on.

\subsection{Internship (Work Practice)}

Internship or practical work is a learning-by-doing process, with the aim of providing practical experience and skills (Duniapcoid, 2020). Through your internship, you will provide experience to control the details of business life, from design concept development to job creation, sales, business operations and customer relationship management. An entrepreneurial internship is a great starting point for starting your own future business (https://absolute internship.com/ internships/entrepreneurship-internships /.)

The entrepreneurship program in the Independent Campus policy is accompanied by internship activities as part of the learning process in business and industrial institutions in particular. It is hoped that students will not only master theory, but also practice to have certain skills and expertise. During the internship, students are expected to be able to absorb everything according to their interests and develop abilities (Rusidi, 2006). Strictly speaking, through apprenticeship students are expected to improve their ability to apply their knowledge and skills, improve communication and social skills, increase student motivation, open opportunities to gain practical experience at work, and so on. Nuraini (2004) and Hodijah et al (no year) suggest that through internships in companies, students can understand planning, study technology and production processes, employee management, business management systems, finance, marketing, quality control and work results, and others.

\subsection{Entrepreneurship Application}

Entrepreneurship seeks to identify new business opportunities through creativity and innovation, 
ambition, independence, courage to take considered risks, for profit, social recognition and market growth (Dornelas, 2018; Kirkley, 2016). Education that contains theories and concepts, as well as apprenticeship activities (practical work) is an important step in implementing an entrepreneurial program, but it must also be accompanied by making business plans and applications. In carrying out entrepreneurship programs, students need to be educated and trained on how to plan, describe strategies for creating or developing a business, and trying to apply them.

A business plan is a document that describes business objectives and what steps must be taken to achieve them, as well as efforts to reduce risk and uncertainty (McKeever, 2016). Developing a business plan and implementing it as part of learning in the entrepreneurship program will be an experience for students to continue these business activities after graduating from college. The business plan and its implementation can become a document as a provision and strategy in fostering entrepreneurship. In other words, entrepreneurial planning and application is a tangible manifestation of student creativity and innovation in seizing business opportunities, so that there is no doubt to continue as an independent work prospect later.

\subsection{Commitment to Sustainability}

In simple terms, commitment can be interpreted as an action to do something without coercion. In the context of the discussion here, commitment to sustainability is an action to create entrepreneurship as employment after students complete their education at college. Commitment arises from the stimulation of theoretical and practical knowledge and skills acquired from college, internships or practical work, or business applications. Commitment to sustainability is a positive response from students towards entrepreneurship education. Education is considered to be accepted happily, becomes an alternative job opportunity, and raises a commitment to continue and realize after graduating from college. Conversely, if it is considered a certain psychological pressure, it will lead to antipathy attitudes and actions and tend to reject it. Various studies show how pressure on something, especially work, has a negative impact on this sustainability commitment (Mowday, 1998; Elangovan, 2001; Mayer \& Natalie, 2002a, 2002b; Samaneh et al, 2011; Robbins \& Coulter, 2018; Colquitt et al, 2015; Sariwulan, Capnary, \& Agung, 2019).

\subsection{Recognition}

The Independent Campus Program requires a guarantee of quality processes and results. The disparity of conditions and situations between tertiary institutions requires certain standards to ensure the quality of processes and results, so that graduates actually meet the expected competencies. In the Independent Campus Guidelines issued by the Directorate General of Higher Education (2020) it is stated that in order for the implementation of the Independent Campus policy, especially the threesemester study rights program outside the study program, is more guaranteed in quality, it is necessary to determine the quality of participant competence, the quality of implementation, the quality of the internal coaching process. and externally, the quality of facilities, the quality of reporting and presentation of results, and the quality of the assessment.

There are no quality assurance indicators. However, several criteria are mentioned to maintain quality and earn the credit points needed. In entrepreneurial activities, quality assurance criteria refer to ownership of business plans and goals (short and long term), successful sales according to business plans, and human resource development in business institutions. However, the problem of recognizing the achievement of student competencies after implementing entrepreneurship programs requires serious attention. The existence of disparities in entrepreneurial programs itself brings its own problems in recognizing the achievement of results. Therefore, the existence of a standardized process and recognition of competency results are important things in supporting the success of this entrepreneurial program. 


\subsection{Theoretical Framework}

Based on the description above, a theoretical framework is built in assessing the study problems.

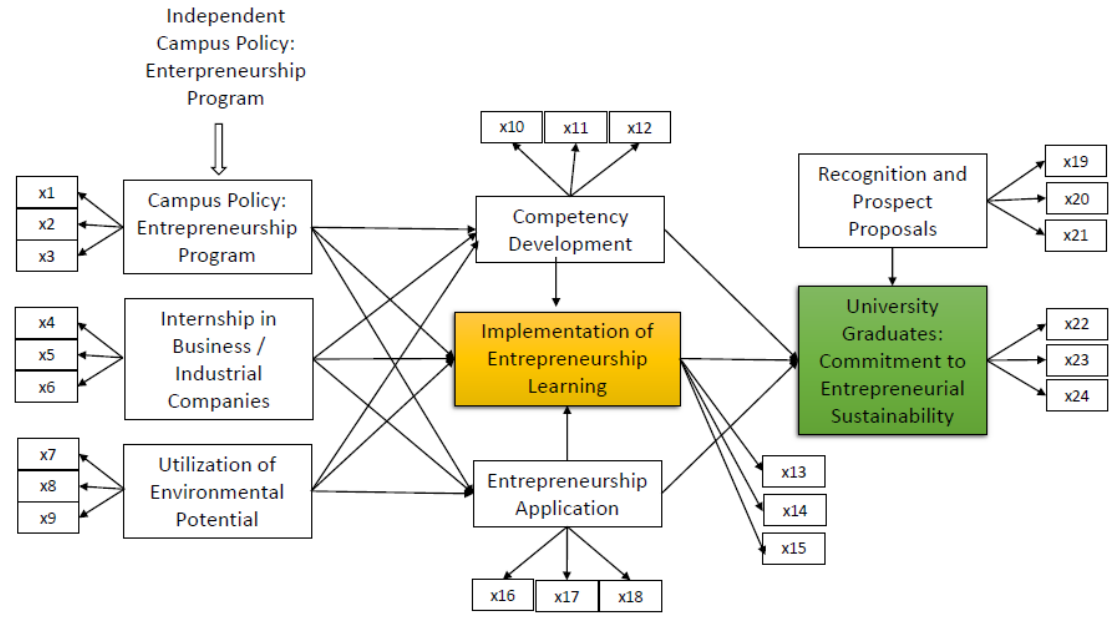

Figure 1. Theoretical Framework Recognition of Entrepreneurship Program in Independent Campus Policies: Indonesian Case

\section{Methodology}

This manuscript is a case study conducted from March to July 2020 at 5 (five) universities with 2 (two) accredited A (Say: University "L" and "M"), and 2 (two) accredited B (Call: University "N" and "O"), and one accredited C (Call: University "P"). There are differences in the characteristics of the universities studied, both between accredited A colleges, and between accredited A with B, and $\mathrm{C}$. The sample universities accredited A for example, both have become state universities with legal status (call: PTNBH), one university has $80 \%$ of study programs have been accredited $\mathrm{A}$ and $20 \%$ are still accredited $\mathrm{B}$, while the other $50 \%$ have been accredited $A$ and $50 \%$ are still accredited $B$ and $C$. The sample universities are still accredited $\mathrm{B}$ and $\mathrm{C}$, most of the study programs are still accredited $\mathrm{B}$ and $\mathrm{C}$ too, and tends not to be ready to apply to become a legal entity (PTNBH) with the ability to explore and collect their own financial resources. However, the five sample universities have formed a working team to implement the Independent Campus policy in accordance with the potential of the institution they have. For example, one part of the policy is to open up opportunities to open new study programs to anticipate, respond, and adapt to developments and changes in the global environment as well as advances in digital technology. Not all universities are able to make it happen due to certain constraints, especially the requirements for the ownership of 5 (five) permanent lecturers, lecture infrastructure, and funding.

As a result of the Covid-19 pandemic situation with the government's mandatory work from home (WFH) regulation, this study also adjusted its strategy in collecting field data and information. Data collection was carried out through on-line discussions about the implementation of the Independent Campus policy, particularly entrepreneurship programs. The study also distributed questionnaires related to questions about entrepreneurship programs to respondents from the Development Team, departmental secretaries, and several other parties. The analysis was carried out through quantitative techniques with the assistance of the LISREL program 87.0 technique, enriched with qualitative techniques based on data and information obtained from on-line discussions, through discussions with stakeholders, ranging from the director general of higher education, experts, research institutions, practitioners, business actors and industry, as well as community organizations. 


\section{Results}

\subsection{Characteristic Respondent}

From the distribution of respondents to five universities, it was obtained 114 respondents who answered the questionnaire. Details 8 (eight) people (7.02\%) came from the leadership and staff of the rectorate, 46 people $(40.35 \%)$ came from the study program, 50 people $(43.86 \%)$ came from lecturers, and 11 people (9, 65\%) others (Postgraduate Directors, industrial entrepreneurs, administrative staff, managers of humanitarian activities, education office officials, and community leaders). Kusnendi (2009) states that the minimum requirement for respondents is 100 people to be used as the basis for the analysis of the LISREL technique.

In the Independent Campus policy, especially the fulfillment of 2 (two) semesters of study outside the campus, the five universities try to carry out 8 (eight) program activities that can be selected by students, namely: (1) student exchange, (2) internships / practical work, (3)) teaching assistance in educational units, (4) research, (5) humanitarian projects, (6) entrepreneurial activities, (7) independent projects, and (8) Thematic Real Work Lecture (TRWL). Student exchange is a crosscampus learning activity (at home and abroad) by living with family at the destination campus. The apprenticeship program is an activity to equip students with sufficient experience by learning directly in the workplace (experiential learning) so that students gain hard skills and soft skills (ethics, professionalism, communication, cooperation, etc.). The teaching assistance program is a teaching activity for elementary, middle and senior high schools, both in cities and in remote areas. Research programs are activities of students in research institutions to build critical thinking, deepen, understand, and be able to do research methods better. Humanitarian programs are student involvement in other humanitarian and development projects. The entrepreneurship program is an activity to develop student businesses from an early age, foster, and at the same time overcome the problem of intellectual unemployment among undergraduates. Independent programs are learning activities to complement the curriculum through cross-disciplinary group work, so that students can develop innovative products that become their ideas; conducts development-based research and education (R\&D); and improve achievement in the national and international arena. The Thematic Real Work Lecture Program (TRWL) is an activity to provide learning experiences to students by living outside the campus, with the community to identify potential and develop village / regional potential.

One of the fulfillments of the 2 (two) rights to learn is entrepreneurship program. The five sample universities have committed to implement it. However, respondents who answered the research questionnaire gave varied opinions. There are those who support this program to be implemented in all study programs at universities, but there are those who answer that it is only intended for certain study programs, especially in the economics faculty. Students who are interested and want to learn more on entrepreneurship program can pick it up in the study program in question. The answers of respondents about the application of entrepreneurship programs can be seen in table 2 below.

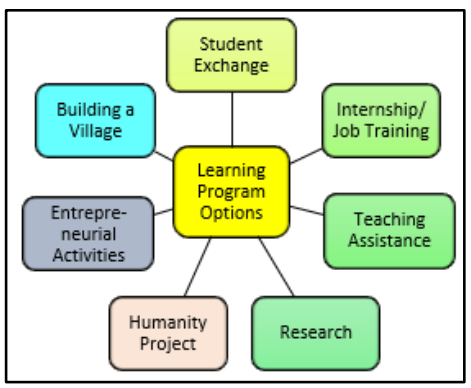

Figure: Student Study Rights Elective Program

Source: Directorate general of Higher Education, 2020. 
Table 2. Respondents' Answers Regarding the Entrepreneurship Program (n=114)

\begin{tabular}{|c|c|c|c|c|c|c|c|}
\hline No. & Question & \begin{tabular}{|l|} 
Strongly \\
Disagree
\end{tabular} & $\begin{array}{l}\text { Disagree } \\
\text { Agree }\end{array}$ & Doubtless & Agree & \begin{tabular}{|c|} 
Strongly \\
Agree
\end{tabular} & Total \\
\hline 1. & Universities should conduct entrepreneurship program. & $\begin{array}{c}8 \\
(7.02)\end{array}$ & $\begin{array}{c}16 \\
(14.04)\end{array}$ & $\begin{array}{c}18 \\
(15.78)\end{array}$ & $\left.\begin{array}{c}35 \\
(30.70)\end{array}\right)$ & $\begin{array}{c}37 \\
(32.46)\end{array}$ & $\begin{array}{c}114 \\
(100.00)\end{array}$ \\
\hline 2. & $\begin{array}{l}\text { Each study program must organize an entrepreneurship } \\
\text { program. }\end{array}$ & $\begin{array}{c}12 \\
(10.53)\end{array}$ & $\begin{array}{c}25 \\
(21.93) \\
\end{array}$ & $\begin{array}{c}20 \\
(17.54)\end{array}$ & $\begin{array}{c}37 \\
(32.46)\end{array}$ & $\begin{array}{c}20 \\
(17.54)\end{array}$ & $\begin{array}{c}114 \\
(100.00)\end{array}$ \\
\hline $3 \cdot$ & $\begin{array}{l}\text { The entrepreneurship education that has been implemented } \\
\text { has attracted high student interest. }\end{array}$ & $\begin{array}{c}16 \\
(14.04)\end{array}$ & $\begin{array}{c}14 \\
(12.28)\end{array}$ & $\begin{array}{c}36 \\
(31.58)\end{array}$ & $\begin{array}{c}25 \\
(21.93)\end{array}$ & $\begin{array}{c}23 \\
(20.17)\end{array}$ & $\begin{array}{c}114 \\
(100.00)\end{array}$ \\
\hline $4 \cdot$ & $\begin{array}{l}\text { Each study program has adequate entrepreneurship } \\
\text { program supervisors. }\end{array}$ & $\begin{array}{c}25 \\
(21.93) \\
\end{array}$ & $\begin{array}{c}22 \\
(19 \cdot 30) \\
\end{array}$ & $\begin{array}{c}14 \\
(12.28) \\
\end{array}$ & $\begin{array}{c}36 \\
(31.58) \\
\end{array}$ & $\begin{array}{c}17 \\
(14 \cdot 91) \\
\end{array}$ & $\begin{array}{c}114 \\
(100.00) \\
\end{array}$ \\
\hline $5 \cdot$ & $\begin{array}{l}\text { Universities / study programs have adequate infrastructure } \\
\text { support for entrepreneurship programs. }\end{array}$ & $\begin{array}{c}26 \\
(22.80)\end{array}$ & $\begin{array}{c}33 \\
(28.95)\end{array}$ & $\begin{array}{c}12 \\
(10.53)\end{array}$ & $\begin{array}{c}27 \\
(23,68)\end{array}$ & $\begin{array}{c}16 \\
(14.04)\end{array}$ & $\begin{array}{c}114 \\
(100.00)\end{array}$ \\
\hline 6. & $\begin{array}{l}\text { The study program has developed an entrepreneurship } \\
\text { program curriculum according to its field. }\end{array}$ & $\begin{array}{c}12 \\
(10.53)\end{array}$ & $\begin{array}{c}23 \\
(20.18)\end{array}$ & $\begin{array}{c}22 \\
(19 \cdot 30)\end{array}$ & $\begin{array}{c}38 \\
(33 \cdot 33)\end{array}$ & $\begin{array}{c}19 \\
(16.67)\end{array}$ & $\begin{array}{c}114 \\
(100.00)\end{array}$ \\
\hline 7. & $\begin{array}{l}\text { The campus has collaborated with the business and industry } \\
\text { world for the implementation of entrepreneurial programs. }\end{array}$ & $\begin{array}{c}10 \\
(8.77)\end{array}$ & $\begin{array}{c}25 \\
(21.93)\end{array}$ & $\begin{array}{c}16 \\
(14.04)\end{array}$ & $\begin{array}{c}42 \\
(36.84) \\
\end{array}$ & $\begin{array}{c}21 \\
(18.42)\end{array}$ & $\begin{array}{c}114 \\
(100.00)\end{array}$ \\
\hline 8. & $\begin{array}{l}\text { The entrepreneurship internship program has been } \\
\text { implemented by the university well., }\end{array}$ & $\begin{array}{c}6 \\
(5.26) \\
\end{array}$ & $\begin{array}{c}13 \\
(11.40) \\
\end{array}$ & $\begin{array}{c}28 \\
(24.56) \\
\end{array}$ & $\begin{array}{c}45 \\
(39.47)\end{array}$ & $\begin{array}{c}22 \\
(19 \cdot 30) \\
\end{array}$ & $\begin{array}{c}114 \\
(100.00)\end{array}$ \\
\hline 8. & $\begin{array}{l}\text { Apprenticeship awakens student enthusiasm to cultivate } \\
\text { entrepreneurship after graduating from college. }\end{array}$ & $\begin{array}{c}20 \\
(17 \cdot 54) \\
\end{array}$ & $\begin{array}{c}15 \\
(13.16)\end{array}$ & $\begin{array}{c}34 \\
(29.82) \\
\end{array}$ & $\begin{array}{c}25 \\
(21.93)\end{array}$ & $\begin{array}{c}20 \\
(17.54)\end{array}$ & $\begin{array}{c}114 \\
(100.00)\end{array}$ \\
\hline 10. & $\begin{array}{l}\text { The campus provides financial assistance for students to } \\
\text { carry out entrepreneurship. }\end{array}$ & $\begin{array}{c}34 \\
(29.82) \\
\end{array}$ & $\begin{array}{c}26 \\
(22.81)\end{array}$ & $\begin{array}{c}15 \\
(13.16)\end{array}$ & $\begin{array}{c}28 \\
(24 \cdot 56)\end{array}$ & $\begin{array}{c}11 \\
(9.65)\end{array}$ & $\begin{array}{c}114 \\
(100.00)\end{array}$ \\
\hline 11. & $\begin{array}{l}\text { The success of the entrepreneurial program is shown that } \\
\text { quite a number of graduates have become entrepreneurs. }\end{array}$ & $\begin{array}{c}22 \\
(19 \cdot 30) \\
\end{array}$ & $\begin{array}{c}28 \\
(24 \cdot 56) \\
\end{array}$ & $\begin{array}{c}35 \\
(30.70) \\
\end{array}$ & $\begin{array}{c}20 \\
(17 \cdot 54) \\
\end{array}$ & $\begin{array}{c}9 \\
(7.89) \\
\end{array}$ & $\begin{array}{c}114 \\
(100.00) \\
\end{array}$ \\
\hline 12. & $\begin{array}{l}\text { The campus monitors and evaluates entrepreneurship } \\
\text { education. }\end{array}$ & $\begin{array}{c}36 \\
(31.58) \\
\end{array}$ & $\begin{array}{c}30 \\
(26.32) \\
\end{array}$ & $\begin{array}{c}20 \\
(17.54)\end{array}$ & $\begin{array}{c}20 \\
(17.54)\end{array}$ & $\begin{array}{c}8 \\
(7.02) \\
\end{array}$ & $\begin{array}{c}114 \\
(100.00) \\
\end{array}$ \\
\hline & Average & $\begin{array}{c}18.92 \\
(16.60)\end{array}$ & $\begin{array}{c}22.5 \\
(19.74)\end{array}$ & $\begin{array}{c}22.5 \\
(19.74)\end{array}$ & $\begin{array}{c}31,5 \\
(27.63)\end{array}$ & $\begin{array}{c}18.58 \\
(16.30)\end{array}$ & $\begin{array}{c}114 \\
(100.00)\end{array}$ \\
\hline
\end{tabular}

Source: Study Recognition of Entrepreneurship Program in Independent Campus Policies: Indonesian Case

\subsection{CFA (Validity-Reliability)}

Confirmatory Factor Analysis (CFA) is one of the widely used validity and reliability tests. CFA to test construct measurement models or confirmatory factor models that show the operationalization of variables into measurable indicators that are formulated in the form of certain equations and / or path diagrams. (Joreskog and Sorborn, 1993; Ferdinand, 2002; Kusnendi, 2008; Hair et al, 2010; Haryono and Wardoyo, 2017; Sarjono and Yulianita, 2019; Yohana, Dania, \& Prihandono, 2021). CFA is carried out as a validity test to determine whether the indicators and variables actually form the latent variables under study by comparing the loading factor of at least 0.5. If the load factor value is greater than 0.5 then the indicator is valid. The reliability test shows how well the measuring instrument can produce relatively similar results if repeated measurements are made on the same object. Reliability value is measured by Construct Reliability (CR) and Variance Extract (VE). It is said to be reliable if the CR> 0.70 and VE> 0.50 (Zakso \& Agung, 2020). Measurement error (ei) is intended to overcome the influence of parameter estimators and variance of large or small sizes, provided that the higher the loading factor value means the smaller the error value, thus indicating that the indicator truly reflects the latent variable. Below is shown the results of the validity and reliability of the indicators of each of the variables studied (table 2). 
Table 3. Validity and Reliability Tests

\begin{tabular}{|c|c|c|c|c|c|c|}
\hline Variables & Indicators & SLF & ei & CR & VE & Conclusion \\
\hline \multirow{3}{*}{$\begin{array}{l}\text { Entrepreneur Program } \\
(\mathrm{EP})\end{array}$} & $\mathrm{X} 1=$ Curriculum development & 0.71 & 0.50 & \multirow{3}{*}{0.8126} & \multirow{3}{*}{0.5925} & \multirow{3}{*}{ Valid \& Reliable } \\
\hline & $\mathrm{X} 2$ = Availability of facilities & 0.74 & 0.45 & & & \\
\hline & $\mathrm{x} 3$ = Adequate companion lecturers & 0.85 & 0.27 & & & \\
\hline \multirow{3}{*}{$\begin{array}{l}\text { Internship in Business } \\
\text { (IB) }\end{array}$} & $\mathrm{x} 4$ = Provision of facilities & 0.80 & 0.36 & \multirow{3}{*}{0.9057} & \multirow{3}{*}{0.7627} & \multirow{3}{*}{ Valid \& Reliable } \\
\hline & X5 = Expert support & 0.92 & 0.20 & & & \\
\hline & $\mathrm{x} 6$ = Complete training modules & 0.91 & 0.16 & & & \\
\hline \multirow{3}{*}{$\begin{array}{l}\text { Utilization Environment } \\
\text { Potential (UEP) }\end{array}$} & $\mathrm{x} 7=$ Ease of production materials & 0.88 & 0.22 & \multirow{3}{*}{0.9412} & \multirow{3}{*}{0.8423} & \multirow{3}{*}{ Valid \& Reliable } \\
\hline & x8 = Marketing prospects & 0.95 & 0.20 & & & \\
\hline & x9 = Low production competitors & 0.97 & 0.07 & & & \\
\hline \multirow{3}{*}{$\begin{array}{l}\text { Competency Development } \\
\text { (CD) }\end{array}$} & $\mathrm{x} 10$ = Mastery production & 0.73 & 0.46 & \multirow{3}{*}{0.8754} & \multirow{3}{*}{0.7025} & \multirow{3}{*}{ Valid \& Reliable } \\
\hline & X11 = Facilities support & 0.92 & 0.16 & & & \\
\hline & $\mathrm{x} 12$ = Marketing strategy & 0.85 & 0.27 & & & \\
\hline \multirow{3}{*}{$\begin{array}{l}\text { Implementation } \\
\text { Entrepreneurship Learning (IEL) }\end{array}$} & $\mathrm{x} 13=$ Curriculum development & 0.77 & 0.41 & \multirow{3}{*}{0.8951} & \multirow{3}{*}{0.7409} & \multirow{3}{*}{ Valid \& Reliable } \\
\hline & $\mathrm{X} 14$ = Support learning facilities & 0.90 & 0.19 & & & \\
\hline & $\mathrm{X} 15$ = Fostering a cooperative relationship & 0.91 & 0.18 & & & \\
\hline \multirow{3}{*}{ Entrepreneur Application (EA) } & x16 = Business guidance & 0.90 & 0.20 & \multirow{3}{*}{0.8138} & \multirow{3}{*}{0.5988} & \multirow{3}{*}{ Valid \& Reliable } \\
\hline & $\mathrm{X} 17=$ Business fund assistance & 0.79 & 0.38 & & & \\
\hline & $\mathrm{x} 18=$ Production tools $/$ materials assistance & 0.61 & 0.63 & & & \\
\hline \multirow{3}{*}{$\begin{array}{l}\text { Recognition Prospect } \\
\text { Proposals (RPP) }\end{array}$} & $\mathrm{X} 19=$ Business funding assistance & 0.90 & 0.18 & \multirow{3}{*}{0.9371} & \multirow{3}{*}{0.8327} & \multirow{3}{*}{ Valid \& Reliable } \\
\hline & $\mathrm{x} 2 \mathrm{O}=$ Standards compliance process & 0.96 & 0.07 & & & \\
\hline & X21 = Entrepreneurial competence & 0.87 & 0.25 & & & \\
\hline \multirow{3}{*}{$\begin{array}{l}\text { Commitment Entrepreneuship } \\
\text { Sustainaibility (CES) }\end{array}$} & $\mathrm{X22}=$ Main job orientation & 0.69 & 0.53 & \multirow{3}{*}{0.9000} & \multirow{3}{*}{0.7535} & \multirow{3}{*}{ Valid \& Reliable } \\
\hline & $\mathrm{X} 23$ = Successful entrepreneurial orientation & 0.96 & 0.08 & & & \\
\hline & $\mathrm{x} 24$ = Independence mentality & 0.93 & 0.13 & & & \\
\hline
\end{tabular}

Source: Study Recognition of Entrepreneurship Program in Independent Campus Policies: Indonesian Case

\subsection{Goodness of Fit Model (GOF Model)}

Goodness of Fit model is a test match or the good fit between the observations (observation frequency) acquired a certain frequency based on the expectation (expected frequencies). Through the test results can be seen whether whole or partial indicators suggest that the model Fit or good, and able to answer the theory is built. In modeling system conformance test is very important, because the analysis of the structural model in SEM started based on statistical indicators Goodness-of-Fit (GFI) on output LISREL (Joreskog and Sorborn, 1993; Hair et al, 2010; Haryono and Wardoyo, 2017; Winingsih \& Suliastono, 2020; Yohana, Dania, \& Prihandono, 2021). Overall, a summary of the critical value of the model match testing can be seen from the summary in table 4 . All indicators show that the SEM model is Fit or good. The data from the questionnaire was able to answer the theory that was built.

Table 4. GOF Model Results

\begin{tabular}{|l|c|c|c|}
\hline Goodness-of-Fit & Cutt-off-Value & Results & Conclusion \\
\hline RMR(Root Mean Square Residual) & $\leq 0,05$ or $\leq 0,1$ & 0.0028 & Good Fit \\
\hline RMSEA(Root Mean square Error of Approximation) & $\leq 0,08$ & 0.0051 & Good Fit \\
\hline P-value & $\geq 0,05$ & 0.18745 & Good Fit \\
\hline GFI(Goodness of Fit) & $\geq 0,90$ & 0.95 & Good Fit \\
\hline AGFI(Adjusted Goodness of Fit Index) & $\geq 0,90$ & 0.94 & Good Fit \\
\hline CFI (Comparative Fit Index) & $\geq 0,90$ & 0.97 & Good Fit \\
\hline Normed Fit Index (NFI) & $\geq 0,90$ & 0.98 & Good Fit \\
\hline Non-Normed Fit Index (NNFI) & $\geq 0,90$ & 0.97 & Good Fit \\
\hline Incremental Fit Index (IFI) & $\geq 0,90$ & 0.95 & Good Fit \\
\hline Relative Fit Index (RFI) & $\geq 0,90$ & 0.95 & Good Fit \\
\hline
\end{tabular}

Source: Study Recognition of Entrepreneurship Program in Independent Campus Policies: Indonesian Case 


\subsection{Structural Relationship Analysis}

The GOF Model requirements which are categorized as good fit become the basis for further analysis to determine the relationship between variables and indicators in them. Using the help of the LISREL 8.70 program, the structural model under study is produced, as follows.

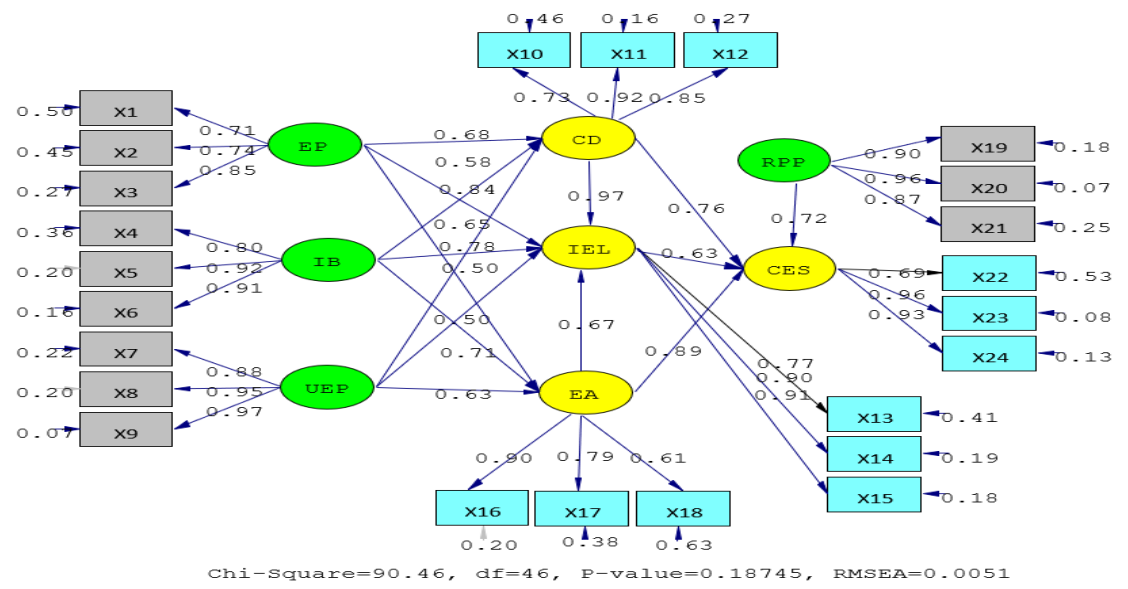

Figure 3. Standardized Loading Factor

Source: Study Recognition of Entrepreneurship Program in Independent Campus Policies: Indonesian Case

The results of the structural relationship analysis in Figure 3 show the hypothesis testing of the variables studied, as in table 5 .

Table 5. Hypothesis Test

\begin{tabular}{|c|c|c|c|}
\hline Hypothesis & SLF & T-Count & Conclusion \\
\hline Entrepreneurship Policy (EP) $\rightarrow$ Competence Development $(\mathrm{CD})$ & 0.68 & 3.37 & Significant Positive \\
\hline Internship in Business (IB) $\rightarrow$ Competence Development (CD) & 0.58 & 2.51 & Significant Positive \\
\hline Utilization Environment Potential (UEP) $\rightarrow$ Competence Development (CD) & 0.84 & 3.71 & Significant Positive \\
\hline Entrepreneurship Policy (EP) $\rightarrow$ Entrepreneurship Application (EA) & 0.65 & 2.18 & Significant Positive \\
\hline Internship in Business (IB) $\rightarrow$ Entrepreneurship Application (EA) & 0.78 & 3.39 & Significant Positive \\
\hline Utilization Environment Potential (UEP) $\rightarrow$ Entrepreneurship Application (EA) & 0.50 & 3.44 & Significant Positive \\
\hline Entrepreneurship Policy (EP) $\rightarrow$ Implementation Entrepeneurship Learning (IEL) & 0.50 & 2.96 & Significant Positive \\
\hline Internship in Business (IB) $\rightarrow$ Implementation Entrepeneurship Learning (IEL)) & 0.71 & 4.63 & Significant Positive \\
\hline Utilization Environment Potential (UEP) $\rightarrow$ Implementation Entrepeneurship Learning (IEL) & 0.63 & 2.76 & Significant Positive \\
\hline Competence Development (CD) $\rightarrow$ Implementation Entrepeneurship Learning (IEL) & 0.97 & 5.03 & Significant Positive \\
\hline Entrepreneurship Application (EA) $\rightarrow$ Implementation Entrepeneurship Learning (IEL) & 0.67 & 3.94 & Significant Positive \\
\hline Competence Development (CD) $\rightarrow$ Commitment Entrepreneuship Sustainaibility (CES) & 0.76 & 4.37 & Significant Positive \\
\hline Entrepreneurship Application (EA) $\rightarrow$ Commitment Entrepreneuship Sustainaibility (CES) & 0.63 & 3.38 & Significant Positive \\
\hline Implementation Entrepeneurship Learning (IEL) $\rightarrow$ Commitment Entrepreneuship Sustainaibility (CES) & 0.89 & 3.13 & Significant Positive \\
\hline Recognition Prospect Proposals (RPP) $\rightarrow$ Commitment Entrepreneuship Sus & 0.72 & 6.97 & Significant Positive \\
\hline
\end{tabular}

Source: Study Recognition of Entrepreneurship Program in Independent Campus Policies: Indonesian Case

\section{Discussion}

Table 5 shows that the entrepreneurial policy variable (EP) has a positive effect on competency development (CD) with a coefficient value of 0.68 , the application of entrepreneurship (EA) with a 
coefficient value of 0.65 , and on the implementation of entrepreneurship learning (IEL) with a coefficient value. o.50. It appears that the influence of entrepreneurship policies (EP) on competency development (CD) and entrepreneurship application (EA) is greater than the implementation of entrepreneurship learning (IEL). These results indicate that entrepreneurship education policies by universities are more useful as a reference for competency development by study programs and support student entrepreneurship applications than for the implementation of entrepreneurship learning. Even so, the positive influence on the implementation of entrepreneurship learning provides a basis for commitment, strengthening, and support for study programs to develop entrepreneurship education.

Internship in Business (IB) also has a positive effect on competency development (CD) with a coefficient of 0.58 , the application of entrepreneurship (EA) with a coefficient of 0.78 , and on the implementation of entrepreneurship learning (IEL) with a coefficient of o.71. From these results, it shows that the effect of apprenticeship is greater on entrepreneurial applications, so that apprenticeship in the business world and the industrial world needs to be linked to the application of entrepreneurial activities by students. Apprenticeship will lead more to the cultivation of practical skills. Internships also have a positive effect on the implementation of entrepreneurship learning, in the sense that they must be part of entrepreneurship education planning, not something sudden, not integrated, and just providing work practice.

Utilization of Environmental Potential (UEP) has a positive influence on competency development (CD) with a coefficient of 0.84 , application of entrepreneurship (EA) with a coefficient of 0.50 , and implementation of entrepreneurial learning (IEL) with a coefficient of 0.63 . It appears that the Utilization of Environmental Potential (UEP) has a greater influence on the development of entrepreneurial competence (CD), so it can be interpreted that entrepreneurship education must be sensitive to the potential and utilization of the surrounding environment, both physical and social. Competency development contains scientific theories and concepts related to entrepreneurship education, is also integrated with basic materials and practices that come from the environment. The potential of the environment as a source of entrepreneurship education will be more attractive and accepted by students, not only because they already have skills but also business materials that are easy to obtain and support productivity.

Furthermore, from Figure 3 it can be seen that the effort to develop entrepreneurial competence (CD) has a greater positive effect with a coefficient of 0.98 than the effect of the application of entrepreneurship (EA) of 0.68 on the implementation of entrepreneurship learning (IEL). Of the three variables $E A, C D$, and IEL have a positive effect on entrepreneurial commitment, but EA has the most important influence in encouraging student entrepreneurial commitment after graduating from college. This is because students have mastered the knowledge, skills, and practices in trying to get entrepreneurship education, so that they can make it happen after graduating from college.

Then what about the contribution of indicators to each variable? Table 6 shows the calculation of the contribution of indicators for each variable that gives the highest and lowest values. Due to limitations, the analysis here only looks at 3 (three) indicators that are considered to have contributed to each variable.

Table 6. Contribution of Indicators in Variables

\begin{tabular}{|c|l|c|c|c|}
\hline Variables & Indicators & Loading value & Construct Coeff. & Contribution \\
\hline \multirow{3}{*}{ EP } & $\mathrm{x} 1=$ Curriculum development & 0.50 & 0.71 & 0.3550 \\
\cline { 2 - 4 } & $\mathrm{X} 2=$ Availability of facilities & 0.45 & 0.74 & 0.3330 \\
\cline { 2 - 4 } & $\mathrm{X} 3=$ Adequate companion lecturers & 0.27 & 0.85 & 0.2295 \\
\hline \multirow{3}{*}{ IB } & $\mathrm{X} 4=$ Provision of facilities & 0.36 & 0.80 & 0.2880 \\
\cline { 2 - 4 } & $\mathrm{x} 5=$ Expert support & 0.20 & 0.92 & 0.1840 \\
\cline { 2 - 4 } & $\mathrm{x} 6=$ Complete training modules & 0.16 & 0.91 & 0.1456 \\
\hline \multirow{3}{*}{ UEP } & $\mathrm{x} 7=$ Ease of production materials & 0.22 & 0.88 & 0.1936 \\
\cline { 2 - 4 } & $\mathrm{x} 8=$ Marketing prospects & 0.20 & 0.95 & 0.1900 \\
\cline { 2 - 4 } & $\mathrm{x} 9=$ Low production competitors & 0.07 & 0.97 & 0.0679 \\
\hline
\end{tabular}




\begin{tabular}{|c|c|c|c|c|}
\hline Variables & Indicators & Loading value & Construct Coeff. & Contribution \\
\hline \multirow{3}{*}{ CD } & $\mathrm{X} 10=$ Mastery production & 0.46 & 0.73 & 0,3358 \\
\hline & X11 = Facilities support & 0.16 & 0.92 & 0.1472 \\
\hline & X12 = Marketing strategy & 0.27 & 0.85 & 0.2295 \\
\hline \multirow{3}{*}{ IEL } & x13 = Curriculum development & 0.41 & 0.77 & 0.3157 \\
\hline & x14 = Support learning facilities & 0.19 & 0.90 & 0.1710 \\
\hline & $\mathrm{x} 15=$ Fostering a cooperative relationship & 0.18 & 0.91 & 0.1638 \\
\hline \multirow{3}{*}{ EA } & $\mathrm{x} 16=$ Business guidance & 0.20 & 0.90 & 0.1800 \\
\hline & $\mathrm{x} 17=$ Business fund assistance & 0.38 & 0.79 & 0.3002 \\
\hline & $\mathrm{x} 18=$ Production tools / materials assistance & 0.63 & 0.61 & 0.3843 \\
\hline \multirow{3}{*}{$\mathrm{RPP}$} & $\mathrm{x} 19=$ Business funding assistance & 0.18 & 0.90 & 0.1620 \\
\hline & $\mathrm{x} 2 \mathrm{O}=$ Standards compliance process & 0.07 & 0.96 & 0.0672 \\
\hline & x21 = Entrepreneurial competence & 0.25 & 0.87 & 0,2175 \\
\hline \multirow{3}{*}{ CES } & $\mathrm{x} 22$ = Main job orientation & 0.53 & 0.77 & 0.4081 \\
\hline & x23 = Successful entrepreneurial orientation & 0.08 & 0.96 & 0.0768 \\
\hline & x24 = Independence mentality & 0.13 & 0.93 & 0,1235 \\
\hline
\end{tabular}

Source: Study problema recognition of entrepreneurship programs in independent campus policies: Indonesian case, 2020.

From the entrepreneurial policy (EP) issued by the university, this study uses 3 (three) indicators that are considered to contribute to these variables, namely: curriculum development (xi), availability of facilities ( $\left.\mathrm{x}_{2}\right)$, and adequate companion lectures $\left(\mathrm{x}_{3}\right)$. From the three indicators, it can be seen that curriculum development (x1) contributed the highest score to EP of 0.3550 , followed by the availability of facilities (x2) of 0.3330 , and adequate companion lectures (x3) of 0.2295 . These results indicate that higher education policies that provide flexibility to develop curricula are welcomed by study programs that provide entrepreneurship education. In addition, support for the provision of facilities, ranging from lecture infrastructure, funding for activities, smooth collaboration with the business world and the industrial world, etc. are considered quite important in entrepreneurship education, accompanied by the preparation of lecturers as student learning companions.

This paper used 3 (three) indicators to see the contribution to the Internship of Business variable, namely: facility provision ( $\left.\mathrm{x}_{4}\right)$, expert support $\left(\mathrm{x}_{5}\right)$, and a complete training module $\left(\mathrm{x}_{6}\right)$. The facility provision indicator $\left(\mathrm{x}_{4}\right)$ contributed the highest value to the business apprenticeship variable (IB) of 0.2880 , followed by expert support $\left(\mathrm{x}_{5}\right)$ of 0.1840 , and a complete training module $\left(\mathrm{x}_{6}\right)$ of 0.146 . These results indicate that the availability of facilities in apprenticeship / practical work is considered a priority for students in supporting entrepreneurship learning in industry and industry, supported by the presence of adequate experts. The completeness of the training module is placed in the third position in this program.

In the utilization of environmental potential (UEP), 3 (three) indicators are used to see the contribution given to this variable, namely: ease of production materials $\left(\mathrm{x}_{7}\right)$, marketing prospects ( $\mathrm{x} 8$ ), and low production competitors (x9). It is explicitly seen that the ease of supply of production materials / materials is an indicator that is considered a priority, followed by its marketing prospects. The level of business competitors is not considered a problem, because of the interest and freedom of consumers to choose what they like. The latter is even thought to lead to healthy competition to increase the production of goods and services, and attract customers. Competition benefits the consumers themselves.

In competency development (CD) using 3 (three) indicators that are considered to contribute to this variable, namely: mastery of production (x10), supporting facilities (x11), and marketing strategy (x12). Indicators of mastery of production theory and concepts, particularly those based on local potential (x10), contributed the highest value to competency development $(C D)$ of 0.3358 , followed by marketing strategy (x12) of 0.2295 , and support facilities (x11) amounting to 0.1475 . The results of this study indicate that entrepreneurship education does not only need to direct learning to theories and 
concepts in science, but also mastery of local potential-based production businesses. Local potential is the basis for the development of entrepreneurial creativity and innovation, so it is hoped that it is truly appropriate and can meet the needs of the surrounding community. This will also facilitate production marketing strategies for entrepreneurship development. Support for learning facilities related to entrepreneurship education, particularly related to the utilization of local potential, also needs to be considered in developing this competency.

The application of entrepreneurship (EA), namely actual business practices in entrepreneurship education, uses 3 (three) indicators to determine its contribution to this variable, namely: business guidelines (x16), business fund assistance (x17), and assistance with production tools / materials (x18). The production equipment / material assistance indicator (x18) gave the highest value contribution of 0.3843 , followed by the business fund assistance indicator (x17) of 0.3002 , and business guidance (x16) of 0.1800 . This shows that entrepreneurship education efforts need to be adjusted to the potential of the environment, especially the use of tools and the acquisition of materials to make it easy, smooth, and to maintain the continuity of production processes and results. In addition, financial assistance from universities or others in entrepreneurship education is considered an important element in the application of entrepreneurship, so that students can actually apply it, not just accept theories, concepts, or practices received in internships. Other indicators that are considered important are guidance assistance in doing business, both related to management, organization, production processes (types and procurement of materials, tools, quality assurance, etc.), marketing strategies, and others.

In the implementation of entrepreneurship learning (IEL), 3 (three) indicators that contribute to this variable are also used, namely: curriculum development (x13), support for learning facilities (x14), and fostering cooperative relationships (x15). From the three indicators, it appears that the development of entrepreneurship curriculum (x13) provides the largest contribution to the IEL variable of 0.3157 , supported by learning facilities (x14) of 0.1710 , and fostering of cooperative relationships (x15) of 0.1638 . The development of the entrepreneurship curriculum that gets the highest score is not limited to the theories, concepts, and practices given related to science, but also everything that comes from local potential. Learning facility support (x16) is placed in second place which shows the importance of this support for entrepreneurship education, and in third position on the importance of relationships with parents, communities, local government, entrepreneurs, and others.

All of the above variables have a positive effect on students' commitment to becoming entrepreneurs after graduation (CES). The indicator that gives the biggest contribution to this CES variable is orientation to make the main job (x22) of 0.4081 , followed by mentality support to be independent by creating employment (x24) of 0.1255 , and orientation to success as an entrepreneur (x23) of 0.672 . They seem to think that if it is difficult to get a job in the government or private sector, entrepreneurship can be an alternative to creating jobs. But they realize that entrepreneurship also requires an independent mentality. They also do not know whether entrepreneurship will result in success or not, but are trying to do it.

One thing that needs to be underlined is that the commitment to develop entrepreneurship needs to be supported by competency recognition. Entrepreneurship education needs to be supported by having competency as a reinforcement for running a business, one of which is by issuing certificates of expertise and skills. Entrepreneurial competence (x21) clearly contributes the highest score for this recognition, which is 0.2175 . Furthermore, competency recognition will strengthen students to compile and submit proposals for business funding assistance (x21), whether issued by the government (for example: small and medium business assistance) or bank credit. The data also records the contribution of the business aid indicator (x19) to the recognition variable of 0.1620 . In recognition also reflected the expertise and skills acquired in entrepreneurship education has been through a certain process standards that ensure that competency. 


\section{Conclusion}

In this study, it was found that the entrepreneurship program policies by universities, apprenticeships, and the utilization of environmental potentials had a positive effect on competency development, application and implementation of entrepreneurship learning. All of these things have a positive impact in creating a commitment to continue and foster entrepreneurship as a source of income. Therefore, all of these variables need to be considered in entrepreneurship education for students, in order to really achieve the expected goal, in antaranyya increase the number of entrepreneurs and overcome unemployment of college graduates.

Entrepreneurship education must also give recognition to students who carry it out, as a strengthening of competence and submitting proposals to get funding assistance from the government and banks. Ownership of competencies and feasibility of proposals will be the basis for student consideration to get financial assistance and realize entrepreneurial desires. If not, entrepreneurship education will only run in vain, without the ability to attract college graduates to do this work which requires a mentality of independence, creativity, innovation, courage to take risks, and so on.

\section{References}

Bisnis. (2019). Hipmi Ready to Boost the Number of New Entrepreneurs in Indonesia. https://www. Hipmi Ready to Boost the Number of New Entrepreneurs in Indonesia jawapos.com/ekonomi/bisnis/28/o6/2019/hipmi-siapdongkrak-jumlah-pengusaha-baru-di-indonesia/

Central Statistics Agency. (2019). Open Unemployment Statistics Data Based on Education 2014 - 2018. Jakarta: Central, Jakarta: Central Statistics Agency.

Central Statistics Agency. (2019). Statistics Indonesia, Jakarta: Central Statistics Agency.

Colquitt, J. A., Jeffery A. L., \& Michael J. W. (2015). Organizational Behavior Improving Performance and Commitmen in the Workplace. New York: McGraw Hill/Irwin.

De Klerk, G. J., \& Kruger, S. (2002). The driving force behind entrepreneurship: An exploratory perspective (Online). htttp://www.kmu.unisg.ch/recontres/bond 2002/F_o4_deKlerl.pdf

Directorate General of Higher Education. (2020). Handbook of Independent Learning - Independent Campus.Jakarta: MOEC Republic of Indonesia.

Dornelas, J. (2018). Entrepreneurship: Turning Ideas Into Business. São Paulo: Empreende.

Drucker, P.F. (2007). Innovation and Entrepreneurship: Practice and Principles. Oxford: Butterworth-Heinemann.

DuBrin, A. J. (2004). Fundamentals of Organizational Behavior. Amazon: Paperback

duniapcoid. (2020). What is an Internship. https://dunia.pendidikan.co.id/magang/

Elangovan, A R (200o) Causal Ordering of Stresss, Satisfaction and Commitment, and Intention to Quit: a Structural Equations Analysis, Leadership \& Organization Development Journal, Vol. 22 (4), 159-165.

Hair Jr. J. F., William C., Black Ba. J.,E Babin R. E. A. (2010). Multivariate Data Analysis. United States: Pearson.

Haryono, S., \& Wardoyo, P (2013). Structural Equation Modeling (SEM) for Management Research with AMOS 18.00. Jakarta: Luxima Metro Media.

Hisrich, R.D., Peters, M.P., \& Sheperd, D. A. (2009), Entrepreneurship. Boston, MA: McGraw-Hill Irwin.

Haryani, S. (2017). Environmental Effect on Entrepreneurship Development of Entrepreneurs in Sleman District, Ekuitas: Journal of Economics and Finance, Vol. 1(1), 24 - 43. DOI: 10.24034/j25485024.y2017.v1.11.1841

Hodijah., Nur'aeni. E. L., Karlimah., Kusdiana, A., \& Rustono, W. S. (no year). Entrepreneurship in the Fending Industry for PGSD UPI Students as a Follow Up the KWU Program. 1-5. http://jurnal.upi.edu/file/Hodijah.pdf https://saintif.com/pengertian-wirausaha/

https://absoluteinternship.com/internships/entrepreneurship-internships/.

Joreskog, K. G, \& Sorborn, D. (1993). LISREL 8. Structural Equation Modeling With the SIMPLIS Command Languanges. Chicago: SSI Inc.

Kao, R. W. Y. (1995). Entrepreneurship: A Wealth-Creation and Value Adding Process, Publisher: Prentice Hall. Kusnendi (2009). Structural Equation Modelling, Bandung: Alfabeta.

Kao, R. W. Y. (1995). Entrepreneurship: A Wealth-Creation and Value Adding Process. Publisher: Prentice Hall.

Kao, R. W. Y. (2006). Defining Entrepreneurship: Past, Present and?. Creativity and Innovation Management, Vol. 2(1):69 - 70, DOI: 10.1111/j.1467-8691.1993.tbooo73.x 
Kardiyono, A. L. (2014). Effectiveness of Self-Development and Entrepreneurial Orientation in Improving Entrepreneurial Attitude. Journal of Intervention Psychology, Vol. $6(1), \quad 25-38$. https://journal.uii.ac.id/intervensipsikologi/article/view/3943/3521

Kirkley, W. W. (2016). Entrepreneurial behaviour: the role of values. International Journal of Entrepreneurial Behaviour \& Research, Vol. 22(3), 290-328. DOI: 10.1108/IJEBR-02-2015-0042

Mayer, J. P., \& Natalie J. A. (2002a). Commitment in the Worplace Theory Research and Application. California: Sage Publications.

Mayer, J. P, \& David J. S. (2002b). Affective, Continuance and Normative Comitment to the Organization: A Metaanalysis of Antecedents, Correlates, and Consequences, Jurnal of Vocational Behavior, Vol. 61 (1), 20-52

McKeever, M. (2016). How to Write a Business Plan. Nolo Publisher.

Meredith, G. G. (1992). Small Business in Australia, Publisher: McGraw-Hill.

Mowday, R. T., Lyman W. P., \& Richard, M. (1998). Organizational linkages: The Psychology of Commitment, Absenteeism, and Turnover. San Diego, California: Academic Press.

Meredith, Grant G., Meredith, G. G., Nelson, R. E, Neck, Neck, P. A., \& International Labor Office. (1982). The Practice of Entrepreneurship, Publisher: International Labor Office.

Montoya, S. (2018). Defining Literacy. Hamburg, Germany: Unesco Institut For Statistics.

Nuraini, H. (2004). Entrepreneurship Internship (MKU) for Students in the "fast food" Nays Café Business. https://repository.ipb.ac.id/handle/123456789/7271

Ratumbuysang, M. F. N. G., \& Rasyid, A. A. (2015). The Role of Parents, Environment, and Entrepreneurship Learning on Entrepreneurship Readiness, Journal of Vocational Education, Vol. 4(1), $15-26$. https://journal.uny.ac.id/files/journals/55/articles/6058/ submission/copyedit/6058-15842-1-CE.pdf

Robbins, S. P., \& Coulter, M. (2018). Management. NJ : Pearson.

Samaneh A., Ali R. K (2011) Emotional Intelligence and Organizational Commitment: Testing the Mediatory Role of Occupational Stresss and Job Satisfaction, Procedia-Social and Behavioral Sciences, Vol. 29, 1965-1976.

Sarjono, H., \& Yulainita, W. (2019). Structural Equation Modeling (SEM): An Introduction, Application for Business Research, Publisher: Salemba Empat.

Sariwulan, T., Capnary, M. C., \& Agung, I. (2019). Contribution of Indicators of Workstress and Organizational Commitment. Business: Theory and Practice Journal, Vol. 20, 293-302. https://doi.org/10.3846/btp.2019.28

Supardi, E., \& Mulyati, S. (2013). Basis of Thinking of Community Entrepreneurship Culture Development Programs and Students. Journal of Social Science Education, Vol. 22 (1). DOI:https://doi.org/10.17509/jpis.v22i1.2198

Susilaningsih. (2015). Education in College Entrepreneurship: Important for All Professions? Journal of Economia, Vol. 11 (1), 1-9. DOI:https://doi.org/10.21831/economia.v11i1.7748

Tan, W. L. (2007). Entrepreneurship as a Wealth Creation and Value-Adding Process. (2007). Journal of Enterprising Culture. Vol. 15, (2), 101-105. Research Collection Lee Kong Chian School Of Business. Available at: https://ink.library.smu.edu.sg/lkcsb_research/ 632

Winingsih, L, H., \& Sulistiono, A. A. (2020). Factors Influencing the Principal's Leadership and Its Impact on Learning Quality and Learning Outcome", Journal of Educational and Social Research, Vol. 10(2), $143-156$. https://doi.org/10.36941/jesr-2020-0034

Yohana, C., Dania, R. F. D., \& Prihandono, D. (2021). Study of the Influence of Education and Literation of Entrepreneurship in Vocational High Schools: Indonesian Case. Academic Journal of Interdisciplinary Studies, Vol. 10(1), 34-50. https://doi.org/10.36941/ajis-2021-0004

Amrazi Zakso, A., \& Agung, I. (2021). Impact of Student Learning at Home Prevent Pandemic Covid-19 in Indonesia. Academic Journal of Interdisciplinary Studies, Vol. 10(2), 228 -239. DOI: https://doi.org/10.36941/ajis-2021-0053

Zimmerer, T. W. (2005). Essentials of Entrepreneurship and Small Business Management. USA: Pearson Prentice Hall. 